\title{
Europe's southernmost glaciers: response and adaptation to climate change
}

\author{
K. GRUNEWALD, ${ }^{1}$ J. SCHEITHAUER ${ }^{2}$ \\ ${ }^{1}$ Leibniz Institute of Ecological and Regional Development, Weberplatz 1, D-01217 Dresden, Germany \\ E-mail: k.grunewald@ioer.de \\ ${ }^{2}$ Landscape Research Centre Dresden, Am Ende 14, D-01277 Dresden, Germany
}

\begin{abstract}
The southernmost glaciers in Europe are located on the Iberian, Apennine and Balkan Peninsulas in mid-latitudes between $41^{\circ} \mathrm{N}$ and $44^{\circ} \mathrm{N}$ at altitudes ranging from 2000 to $3000 \mathrm{~m}$ a.s.l. All these glaciers are a legacy of the Little Ice Age (LIA). They survive in a relatively warm environment (mean annual temperature $0^{\circ} \mathrm{C}$ to $+1^{\circ} \mathrm{C}$ ) due to local topographic controls and high levels of accumulation as a result of avalanche and wind-blown snow. In the Pirin Mountains, Bulgaria, Snezhnika glacieret has been cored, providing an archive of recent climate change. Small glaciers such as this respond quickly to climatic extremes. Since the LIA maximum during the 19th century, all southern European glaciers have retreated, losing $30-100 \%$ of their volume. However, despite the trend towards warmer years since the late 1970s, some glaciers still survive, even after some of the hottest summers on record. Predicted future warming, especially in summer, and drier conditions in the Mediterranean basin may result in the disappearance of all glacier features at these latitudes in Europe within the next few decades.
\end{abstract}

\section{INTRODUCTION}

Numerous mountain ranges in the Mediterranean were covered by glaciers during the Pleistocene. In a classic work, Messerli (1967) documented evidence of glaciation across the Mediterranean mountains and used this evidence to reconstruct the glacial snowline across the region, $\sim 1000 \mathrm{~m}$ lower than the modern snowline in many areas. This was based on Messerli's own field observations and also the works of renowned glacial morphologists such as Louis (1933), Büdel (1949) and Paschinger (1955).

Ghiacciaio del Calderone, Italy, is often cited as the southernmost glacier in Europe. This claim was preceded by Corral del Veleta in the Spanish Sierra Nevada, but this glacier melted at the beginning of the 20th century. Ghiacciaio del Calderone also seems likely to disappear in the near future (Pecci and others, 2001; Meier and others, 2003; Citterio and others, 2007). Southern European glacier features are currently the focus of several different research efforts (e.g. Gellatly and others, 1994; D'Orefice and others, 2000; Federici and Stefanini, 2001; Grove, 2001; Giraudi, 2005; Chueca and others, 2007; Gonzáles Trueba and others, 2008).

Glaciers also exist at similar latitude in the Balkans (Grunewald and others, 2006; Hughes, 2007, 2008, 2009; Grunewald and Scheithauer, 2008a; Milivojevič and others, 2008). However, until recently, little was known about the small glacier forms of this region. In the Prokletije mountains on the Montenegro-Albania border, Roth von Telegd (1923) reported several ice and snow features at the beginning of the 20th century, including Firnmasse, which was $>1 \mathrm{~km}$ long. Today in this area there are still several glaciers that cover areas of up to $0.05 \mathrm{~km}^{2}$ (Milivojevič and others, 2008; Hughes, 2009). These are all situated just north of $42^{\circ} \mathrm{N}$ and are situated well below the climatic snowline. They survive as a result of avalanching and wind-drift snow and shading. Our first aim is to review the current status of Europe's southernmost glaciers and the regional and local climatic and topographic factors controlling their development.
The Balkan Peninsula is situated in the climatic transition between the temperate zone and Mediterranean conditions. It is characterized by a mosaic of mountains, basins and valleys (Grunewald and Stoilov, 1998). In the course of global climatic change it can be assumed that this region will become dryer and warmer. To evaluate the current situation the few existing climate proxy datasets need to be amended by precisely dated and highly time-resolved geoarchives that allow a survey of the past few centuries (Grunewald and Scheithauer, 2008c).

For reconstructing and monitoring current and historical climatic and environmental changes there is a wide spectrum of archives, for example artefacts of soil genesis, sediment and peat layers from silting areas of glacial lakes, ecotones of the timberline, geomorphological forms (moraines) and glaciological data. Of these, glaciological archives most sensitively indicate current climatic changes. Because of their low altitude and southern location, most Balkan mountains are not recently glaciated terrains. Whether or not there are adequate features to observe and reconstruct, climatic and environmental changes are little known in the Balkans since they have been investigated only rarely. Only 100 years ago, glaciers were much more extensive than at present in high mountain areas of the Balkans, and in many of these areas the glaciers have since disappeared.

To understand the response of southern European glaciers (particularly Balkan glaciers) to recent climate change we have studied Snezhnika glacieret, Bulgaria, during the past few years (Grunewald and others, 2006, 2008; Grunewald and Scheithauer, 2008a). Snezhnika is the remains of Vihren glacier in the Pirin Mountains. This glacier patch covers an area of nearly $0.01 \mathrm{~km}^{2}$ and is currently Europe's southernmost glacieret $\left(41^{\circ} 46^{\prime} \mathrm{N}\right)$. Snezhnika glacieret is exceptional, persisting despite a relatively high (and recently increasing) annual mean temperature and low precipitation. To examine the special conditions pertaining to this glacier feature in southeastern Europe we carried out an ice-core 


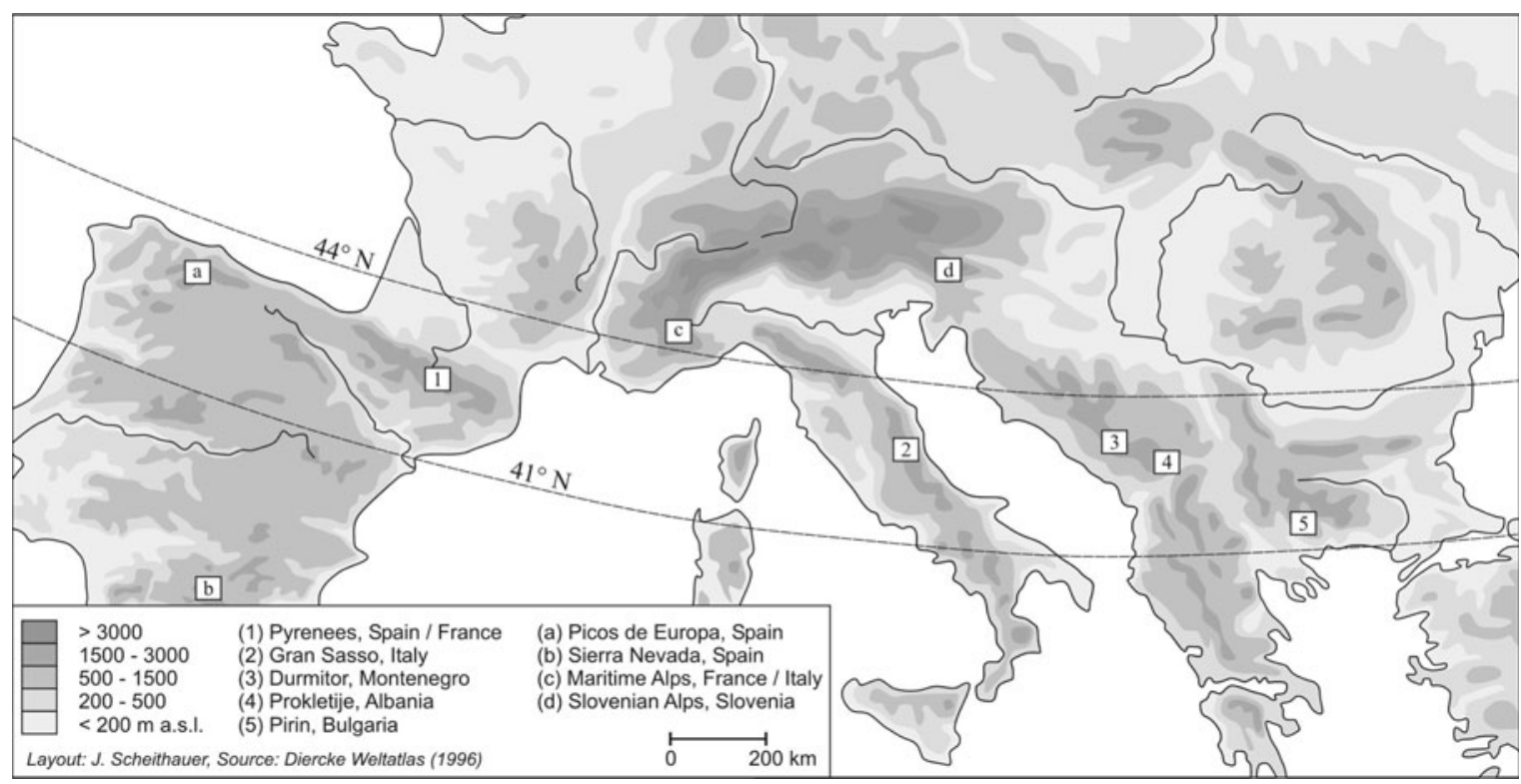

Fig. 1. Location of the southernmost glaciers in Europe.

drilling project on the glacieret. We also consider past climatic and environmental conditions from other geoarchives (e.g. dendrochronology).

\section{RECENT GLACIATION OF HIGH MOUNTAINS IN SOUTHERN EUROPE}

At the beginning of the third millennium, there are only a few small glaciers in southern Europe (Fig. 1). The southernmost of these are situated close to $42^{\circ} \mathrm{N}$. Photographs of selected examples are presented in Figure 2. The Caucasus area is excluded from our investigations, although there is a European part of the Caucasus at approximately $42^{\circ} \mathrm{N}$ where large glaciers appear.

Messerli (1967) described the southern European glaciers as 'Pyrenean type' with the following characteristics: (1) location at the foot of a wall or in a hollow in north to east orientation; (2) an underdeveloped tongue; and (3) a small area, and width often larger than length. Grunewald and others (2006) used the German term 'Mikrogletscher' to describe small dynamic snow and ice features in Bulgaria. Here we use the term 'glacieret' or 'glacier patch' (Maisch and others, 1999a). These features form from either drifted or avalanched snow and/or heavy accumulation in certain years (WGMS, 2008, p. 99). According to Grunewald and others (2006), these glacierets are characterized by: (1) quasi-permanency (relatively reliable for the past few decades back to AD 1850); (2) firn and ice (density $>0.6 \mathrm{~g} \mathrm{~cm}^{-3}$, at the bottom $\sim 0.8 \mathrm{~g} \mathrm{~cm}^{-3}$ ); (3) perennial firn layers; and (4) an area of at least $10000 \mathrm{~m}^{2}$ and thickness of several metres. Moraines on the front or side are typical (Fig. 2), with crevasses often present in the firn, indicating motion (normally rotary motions; Grunewald and Scheithauer, 2008a). At Debeli Namet glacier, Montenegro, Hughes (2007) observed evidence of deformed banding on the glacier surface, suggesting dynamic glacier ice. However, unlike larger glaciers, these are either in the accumulation or in the ablation zone at the end of the melt season. In fact, in some years the entire glacier surface can experience negative mass balance, whilst in high-precipitation years the entire glacier surface can experience positive net balance. This fickle mass-balance behaviour means that defining the equilibrium-line altitude (ELA) is often problematic (Hughes, 2008).

In addition to small glaciers and glacierets, perennial ice, firn and snow patches are also present in southern Europe. They are often accumulations of avalanche and wind-blown snow and survive one or more summers at protected sites at the periglacial altitude level (Stahr and Hartmann, 1999). The transition between ice, firn and snow patches, glacierets and glaciers is not always clear, although for definition as a glacieret or glacier there must be evidence that the ice mass is actively deforming and the ice is moving rather than static (UNESCO/IASH, 1970; Maisch and others, 1999a). An example of problems in defining these features is seen in the Tatra Mountains of Poland and in Slovakia. Here, Jania (1997) calls these features snow patches, whereas Gadek and Kotyrba (2003) refer to glacierets.

\section{Iberian Peninsula}

On the Iberian Peninsula, glaciers are only found in the Pyrenees: 10 glaciers in Spanish territory $\left(2.60 \mathrm{~km}^{2}\right)$ and 11 in French territory $\left(2.35 \mathrm{~km}^{2}\right)$. They are situated in the highest massifs of the central Pyrenees and there are a number of glacierets, ice patches and rock glaciers (Gonzáles Trueba and others, 2008). Table 1 and Figure 2 show Maladeta glacier, a representative example for the present Pyrenean glaciers. The climatic snowline rises strongly from west to east, as there are no glaciers in the eastern Pyrenees despite the fact that there are summits $>3000$ ma.s.l.

In the Picos de Europa (2648 m), Cantabrian Mountains, four partially buried ice patches/glacierets are present. These features are very small and inactive and are relicts of glaciers present during the Little Ice Age (LIA; Gonzáles Trueba, 2006).

The southernmost glacier in Europe was, until the 1920s, Corral del Veleta glacier in the Sierra Nevada $\left(37^{\circ} \mathrm{N}, 3^{\circ} \mathrm{W}\right)$. This glacier was situated in a north-facing cirque beneath $300 \mathrm{~m}$ high cliffs below the highest summit of the Iberian Peninsula (Mulhacán, 3479 m a.s.l.). Today, all that remains 

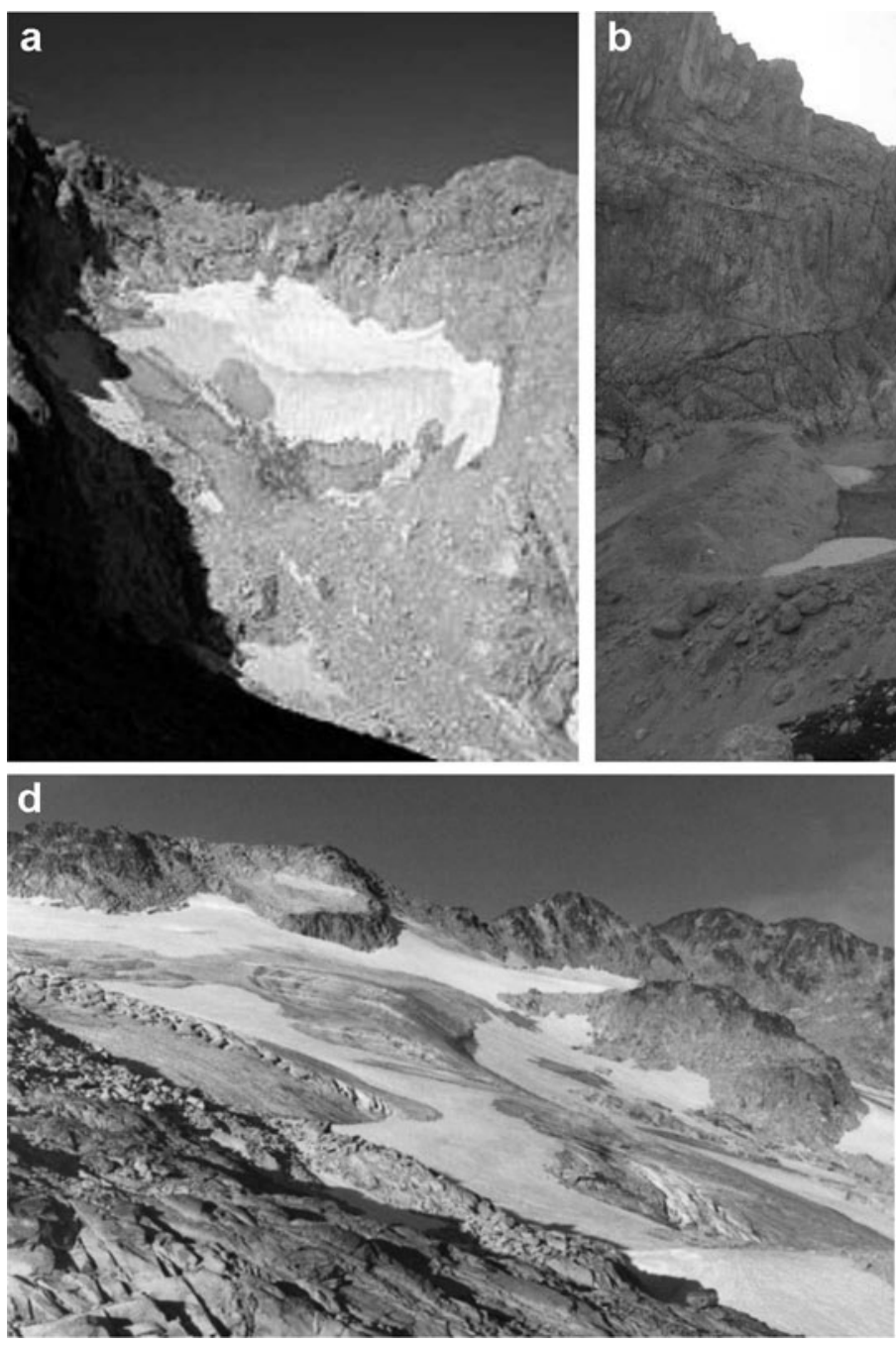
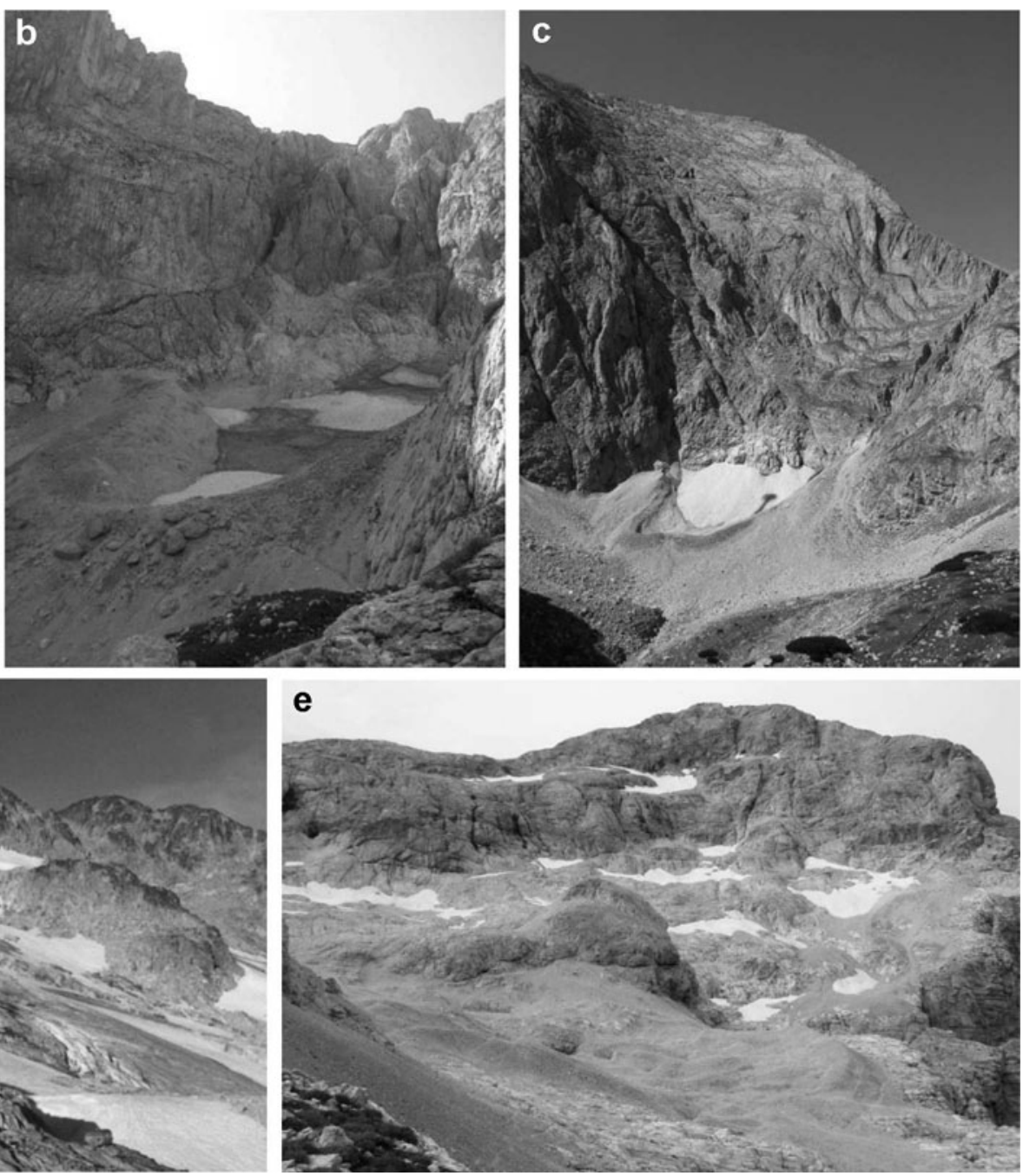

Fig. 2. Photographs of selected southern European glacier features (for location and characteristics see Fig. 1 and Table 1). (a) Calderone glacieret, 2007 (photo F. Spadavecchia); (b) Debeli Namet glacier, 2008 (photo K. Grunewald); (c) Snezhnika glacieret, 2008 (photo K. Grunewald); (d) Maladeta glacier, 2007 (photo J.-P. Girard); and (e) Triglav ice patch, 2006 (photo K. Grunewald).

is some buried ice patches (permafrost) and perennial snow (Gómez Ortiz and others, 2001: Gonzáles Trueba and others, 2008).

\section{Maritime Alps}

The Alpes Maritimes of southern France and western Italy supported 15 small glaciers as recently as the late 20th century (Federici and Pappalardo, 1996). These glaciers are the southernmost of the Alpine chain and some are situated $<50 \mathrm{~km}$ from the Mediterranean Côte d'Azur. Thirteen of the glaciers are found in the Argentera Massif, which contains the highest peaks of the Alpes Maritimes. The ELA of the six largest Argentera glaciers was $\sim 2800$ m a.s.l. in the late 20th century (Finsinger and Ribolini, 2001). In common with other parts of the Mediterranean, all these glaciers have retreated during the last century, and recent glacier behaviour is probably a prelude to the extinction of the glacier ice in the Alpes Maritimes (Federici and Pappalardo, 1996; Pappalardo, 1999).

\section{Italian Apennines}

The Apennine Mountains span the length of the Italian peninsula. The highest peak is Corno Grande (2912 ma.s.I.) in the Gran Sasso of Abruzzi where Ghiacciaio del
Calderone is found. This is Europe's southernmost glacier. The glacier is located below the regional snowline in a steep-sided north-facing cirque (Gellatly and others, 1994) where the local topography creates a microclimate suitable for glacier development. The glacier has retreated through the 20th century. Between 1916 and 1990 its volume is estimated to have reduced by about $90 \%$ and its area by about 68\% (D'Alessandro and others, 2001). The future of Ghiacciaio del Calderone is therefore in doubt, in common with other glaciers of southern Europe (Grove, 2004). In 2009 Ghiacciaio del Calderone was divided into two small glacier patches (glacierets).

Glaciers are not present anywhere else in the Italian Apennines. However, permanent ice has been reported in Sicily in the Grotta del Gelo (Cave of Frost) at $\sim 2030$ m a.s.l. on Mount Etna (Marino, 1992). The cave is situated well below the regional snowline, and again the presence of ice is likely to be controlled by local conditions.

\section{Balkan Peninsula}

The Balkan Peninsula is particularly mountainous, containing mountain ranges between 2000 and nearly $3000 \mathrm{~m}$ a.s.l. from Greece to Slovenia (south-north) and from Albania/ Montenegro to Bulgaria (west-east). Glaciers formed in all 
Table 1. Characteristics of southern European glaciers (representative selection $<44^{\circ} \mathrm{N}$; for location see Fig. 1)

\begin{tabular}{|c|c|c|c|c|c|}
\hline Glacier name & Maladeta & Calderone & Debeli Namet & Maja e Kolacit & Snezhnika \\
\hline Exposition & Northeast & North-northeast & North & North & Northeast \\
\hline Altitude (ma.s.I.) & $2870-3210$ & 2680 & $2080-2290$ & $1980-2100$ & $2430-2480$ \\
\hline Length $(\mathrm{m})$ (year) & $810(2007)$ & $300(2007)$ & $360(2007)$ & $410(2007)$ & $80(2007)$ \\
\hline Country & Spain & Italy & Montenegro & Albania & Bulgaria \\
\hline Mountain range (Fig. 1) & Pyrenees (1) & Apennines (2) & Durmitor Massif (3) & Prokletije (4) & Pirin (5) \\
\hline Highest peak (ma.s.l.) & $\begin{array}{c}\text { Maladeta } \\
3308\end{array}$ & $\begin{array}{c}\text { Corno Grande } \\
2912\end{array}$ & $\begin{array}{c}\text { Šljeme } \\
2455\end{array}$ & $\begin{array}{c}\text { Maja e Jezerces } \\
2694\end{array}$ & $\begin{array}{c}\text { Vihren } \\
2914\end{array}$ \\
\hline \multicolumn{6}{|c|}{ Estimated climate data near the glacier } \\
\hline Precipitation $\left(\mathrm{mm} \mathrm{a}^{-1}\right)$ & 2500 & $>2000$ & $2500-3000$ & $2500-3,000$ & 1000 \\
\hline Mean temperature $\left({ }^{\circ} \mathrm{C}\right)$ & 0.7 & 1 & 0.9 & 0.9 & 0 \\
\hline \multirow[t]{5}{*}{ Area $\left(\mathrm{km}^{2}\right)^{*}$ (year) } & $1.52(1820)$ & $0.104(1794)$ & $0.018(2003)$ & $0.054(2007)$ & $0.013(1959)$ \\
\hline & $0.55(2000)$ & $0.091(1884)$ & $0.041(2005)$ & & $0.004(1994)$ \\
\hline & & $0.060(1934)$ & 0.037 (2007) & & 0.007 (2000) \\
\hline & & $0.053(1990)$ & & & $0.010(2006)$ \\
\hline & & $0.033(2006)$ & & & 0.007 (2008) \\
\hline Max. thickness $(m)^{\dagger}$ (year) & ? & $25(1990)$ & $16(2006)$ & ? (average $\sim 10 \mathrm{~m}$ ) & $12(2006)$ \\
\hline \multirow[t]{4}{*}{ Volume $\left(\mathrm{m}^{3}\right)^{*}$ (year) } & ? & $361000(1990)$ & $122250(2003)$ & $542880(2007)$ & $30000(2006)$ \\
\hline & & & 373500 (2005) & & \\
\hline & & & 489000 (2006) & & \\
\hline & & & $325000(2007)$ & & \\
\hline \multirow[t]{4}{*}{ Source } & Chueca and others & D'Orefice and others & Hughes $(2007,2008)$ & Hughes (2009) & Popov (1964); \\
\hline & $(2007)$ & $\begin{array}{c}\text { (2000); D'Alessandro } \\
\text { and others (2001); }\end{array}$ & & & $\begin{array}{l}\text { Grunewald and } \\
\text { others (2006); }\end{array}$ \\
\hline & & Pecci and others (2001) & & & Grunewald and \\
\hline & & $\begin{array}{l}\text { A. Di Paola, http:// } \\
\text { nuke.ilcalderone.biz }\end{array}$ & & & $\begin{array}{c}\text { Scheithauer } \\
\text { (2008a) }\end{array}$ \\
\hline
\end{tabular}

*Measurement: ground/field topography, GPS, tape, photogrammetric, aerial and ground control.

${ }^{\dagger}$ Measured by drilling or calculated using an empirical volume-area relationship (Chen and Ohmura 1990).

Estimated from average area and thickness.

these mountains during the Pleistocene (Hughes and others, 2006b). However, recent research has also revealed new evidence of small modern glaciers in the Balkans (Grunewald and others, 2006; Hughes, 2007, 2008, 2009; Grunewald and Scheithauer, 2008a; Milivojevič and others, 2008).

Modern glaciers do not exist in Greece since the permanent snowline is situated well above most of the highest peaks. The snowline was above $3000 \mathrm{~m}$ a.s.l. in the Pindus Mountains of northern Greece and above $3500 \mathrm{~m}$ across Crete during the middle of the 20th century (Messerli, 1980), but has risen in the past few decades.

Further north in the Bulgarian Pirin Mountains, Grunewald and others (2006) mapped two glacierets and several firn patches. Snezhnika glacieret $\left(41^{\circ} 46^{\prime} \mathrm{N}, 23^{\circ} 40^{\prime} \mathrm{E}\right)$ at the foot of the north wall of the peak, Vihren (2914 ma.s.I.), is currently the southernmost glacial mass in Europe (Table 1; Fig. 2). The adjacent Rila Mountains to the north are free of ice due to silicate rock, although the highest summit of the Balkan Peninsula (Musala, 2925 m a.s.l.) is found here.

Further north and west, there are glaciers up to $0.05 \mathrm{~km}^{2}$ in area in Albania and Montenegro. In the central part of Prokletije mountain (Albanian Alps, 2694 ma.s.I.), Milivojevič and others (2008) detected three glaciers with moraines and two rock glaciers in cirques about $2000 \mathrm{~m}$ a.s.l., which are situated within ridges $>400 \mathrm{~m}$ high. Debeli Namet glacier is further north, in the Montenegrin Durmitor massif (Table 1; Fig. 2). The glaciers of Albania and Montenegro represent some of the lowest-altitude glaciers (about
$2000 \mathrm{~m})$ at this latitude $\left(42-44^{\circ} \mathrm{N}\right)$ in the Northern Hemisphere (Hughes, 2008, 2009).

In the northern Balkans, two glaciers are located in the mountains of Slovenia. On Triglav mountain (2864 ma.s.I.) in the Julian Alps of Slovenia, Zeleni Sneg glacier is situated on the northern slopes between $\sim 2550$ and 2400 ma.s.l. By 1995 the glacier covered an area of only $0.0303 \mathrm{~km}^{2}$ (Gabrovec, 1998). Increases in summer temperatures and maximum daily temperatures from May to September between 1954 and 1994 are closely correlated with the retreat of the glacier front and a reduction in ice thickness (Gams, 1994). In addition, a small glacieret is located at the foot of the $700 \mathrm{~m}$ high Skuta north face in the Steiner Alps at $\sim 1700$ ma.s.I., considerably lower than the regional snowline (Pavšek, 2004).

\section{Synthesis: factors and regionalization}

The small number of glaciers and glacierets in favoured sites in southern Europe indicates that the recent regional climatological ELA is above the altitude of the summits (e.g. Messerli, 1967; Gonzáles Trueba and others, 2008; Hughes and Woodward, 2009).

Figure 3 illustrates the factors that influence the formation and dynamics of small glaciers and glacier patches in the mountains of southern Europe. Europe's southernmost glaciers are currently found at altitudes between 2000 and $3000 \mathrm{~m}$ and at latitudes between $41^{\circ} \mathrm{N}$ and $44^{\circ} \mathrm{N}$ (Fig. 1; Table 1). The size of the glaciers varies from $\sim 800 \mathrm{~m}$ in length and $0.1-1.0 \mathrm{~km}^{2}$ in the Pyrenees (Gonzáles Trueba 


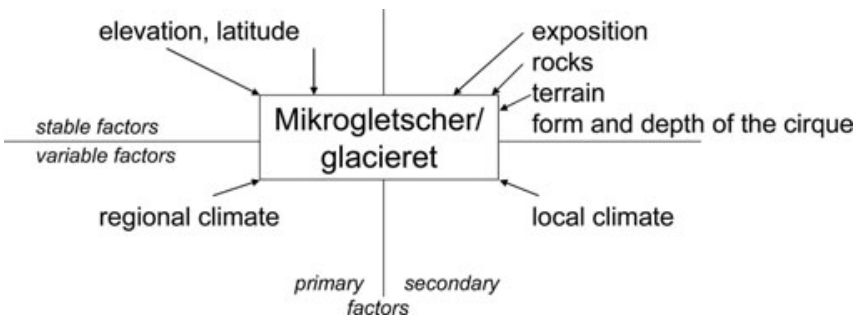

Fig. 3. Basic formation factors of small glacier features.

and others, 2008), up to 300-400 $\mathrm{m}$ in length and 0.03$0.05 \mathrm{~km}^{2}$ in the western Balkans and to almost $100 \mathrm{~m}$ in length and $0.005-0.015 \mathrm{~km}^{2}$ (glacier patches) in the Pirin Mountains (eastern Balkans).

All regions show a relatively 'warm' and 'wet' mountain climate with oceanic, Mediterranean or continental moderate conditions (west-east). The annual mean temperatures in the glacier areas are estimated at $0^{\circ} \mathrm{C}$ to $+1^{\circ} \mathrm{C}$ (Table 1) which is normally much too warm for glacier persistence. The fact that conditions are 'warm' at the glacier sites in southern Europe means that large amounts of accumulation are required to offset melting (Ohmura and others, 1992; Kaser, 2001).

The topography and exposure of the southern European glacier sites are very similar. They all survive in north/ northeast-facing locations within very steep cirque walls below the highest summits. This applies especially to Calderone, Debeli Namet and Snezhnika glaciers (Fig. 2). They are thereby protected against perpetual, intensive and direct summer radiation. The glaciers persist below the ELA because of substantial inputs from avalanches and windblown snow. For example, Hughes (2008) showed that the annual accumulation required to balance melting at Debeli Namet glacier was 5000-6000 mm w.e. but the precipitation in the high mountain area is only $2500-3000 \mathrm{~mm}$ (Table 1 ). Thus local sources of snow input must effectively double the accumulation to preserve the glacier.

The underlying lithology is also relevant. Limestone and marble rock form small and deep cirques, promoted by the occupation and excavation of pre-existing dolines (Hughes and Woodward, 2009). These light-coloured carbonate rock types also typically exhibit high albedo (Popov, 1964). Furthermore, due to karstification, meltwater quickly trickles away (e.g. no cirque lakes persist as thermal storage systems).

\section{INVESTIGATION METHODS AND APPLICATION TO SNEZHNIKA GLACIERET}

Three drillings were carried out in September 2006 at Snezhnika glacieret (Grunewald and Scheithauer, 2008a) using a Ruefli driller provided by the Alfred Wegener Institute, Potsdam, Germany. The drill is equipped with: (1) a circular cutter with three knives which cut a ring into the ice, leaving the core $(70-100 \mathrm{~cm}$ in length, $10 \mathrm{~cm}$ in diameter) in the centre; (2) glass-fibre leverage up to $16 \mathrm{~m}$ (13 individual extensions) and additional equipment (tools, scale, spare parts, etc.); and (3) hand crank, motor cap, fuel, transport and cooler boxes (altogether $\sim 60 \mathrm{~kg}$ ).

Figure 4 shows the position of the drillholes, each vertical and to the bottom of the ice. Depths of $7.8 \mathrm{~m}$ (site BOA),

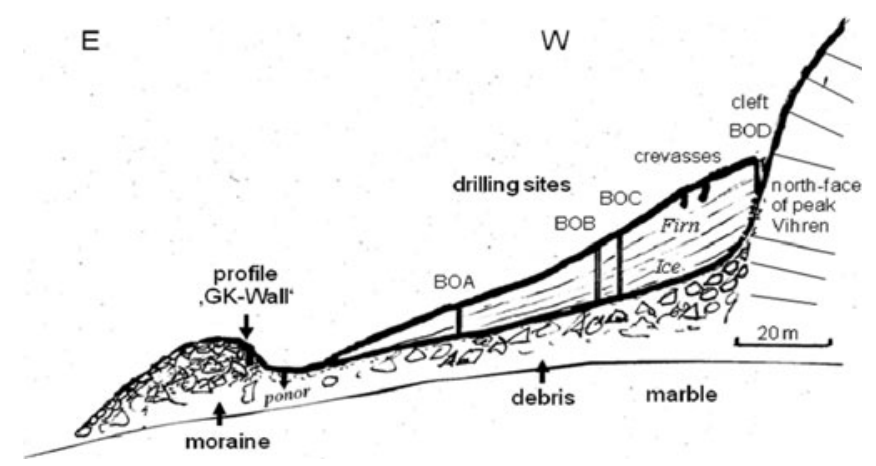

Fig. 4. Profile of Snezhnika glacieret showing position of the coredrilling sites.

$10.9 \mathrm{~m}(\mathrm{BOB})$ and $11 \mathrm{~m}$ (BOC) were reached. BOD marks the position of the investigation at the cleft in 2004, described by Grunewald and others (2006). Processing in the field consisted of core description (stratification, characteristics), photographs, core physical and chemistry measurements, borehole temperature, weighing and core packing. Core density, ion content and isotope ratio were measured in the laboratory to reconstruct climate and environment indicators.

Numerous boundary layers were identified in the cores. However, to a large extent these boundary layers do not separate homogeneous layers of a mass-balance year but several alternating soft and hard layers. The layers represent larger precipitation or avalanche events in the upper zone; at depth they are compressed. A sloping stratification of $\sim 30-45^{\circ}$, analogous to the gradient of the bedrock and the surface of the glacieret, was determined. Characteristic features included layers with a reddish colouration in snow, firn and ice (probably due to Sahara dust) and ice lamellae due to surface melting or rock layers (culm) of up to $2 \mathrm{~cm}$ thickness close to the bottom. In total, 125 layers were sampled (BOA: 44; BOB: 47; BOC: 34). The layers were divided into categories (1: old snow; 2: firn; 3: firn ice; 4: ice) based on colour, consistency and particle size, and the density measurements were verified. Spearman's rank correlations were determined to analyse the relation between parameters. Several significant relationships between individual parameters were identified (Grunewald and Scheithauer, 2008a). Cluster analyses of the data according to the Ward method confirmed the element combination. We found logical relations between: (1) the depth profiles and density; (2) the $\mathrm{pH}$ value, $\mathrm{Ca}^{2+}$ and conductivity (ion dominance of the calcium, probably because of the location close to the marble wall and therefore alkalinity with depth); and (3) nitrate, sulphate and $\delta^{18} \mathrm{O}$ - the depth pattern may be the result of a common atmogenic origin and similar translocation processes in the glacier (molecular size and integration in firn/ ice crystals).

The high densities in the firn profiles, which increase from top to bottom as well as from site BOA to site BOC (Figs 4 and $5 \mathrm{a})$, i.e. towards the marble wall, characterize the important role that the freeze-thaw cycle plays in determining the structure of Snezhnika glacieret. Such densities $\left(>0.815 \mathrm{~g} \mathrm{~cm}^{-3}\right)$ generally occur at depths between 50 and $100 \mathrm{~m}$ in polar regions where the snow metamorphosis is influenced only to a small extent (if at all) by melt or water 

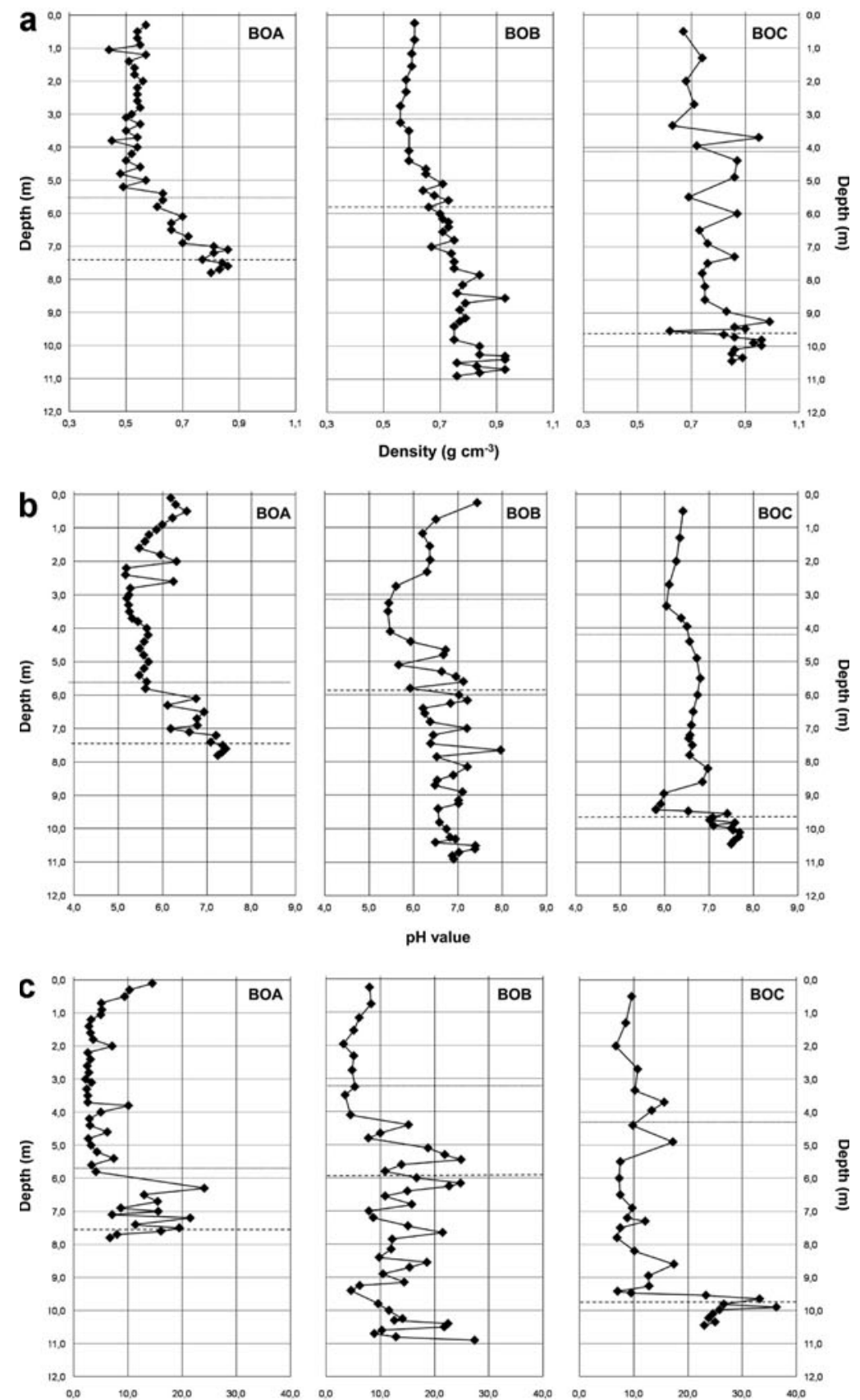

Conductivity $(\mu \mathrm{S} \mathrm{cm}-1)^{*}$

- Three values are greater than 40 - BOA depth $6.1 \mathrm{~m}\left(62.0 \mathrm{HS} \mathrm{Cm}^{-1}\right)$ BOB $9.73 \mathrm{~m}(45.4)$ and $\mathrm{BOC} 10.03 \mathrm{~m}(63.8)$
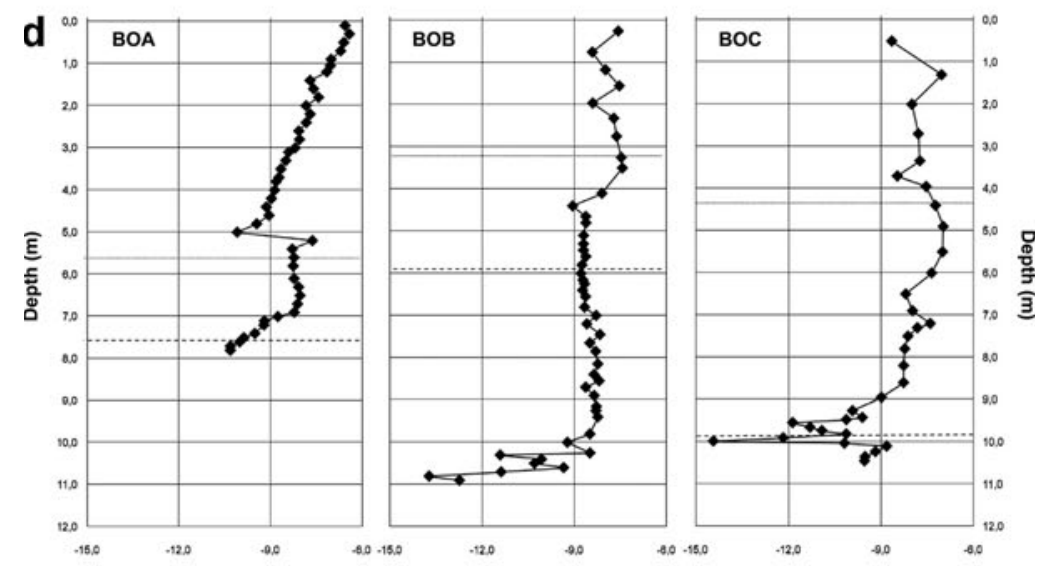

Stable isotope $\delta^{18} \mathrm{O}(\%)$

Fig. 5. Plots against depth of (a) density, (b) pH value, (c) conductivity and (d) stable-isotope ratio for each of the three cores BOC, BOB and BOA. The dotted horizontal lines indicate the transition depth between old snow and firn. The dashed horizontal lines indicate the transition depth from firn to ice. 
Table 2. Medians and means of core physics and chemistry measurements

\begin{tabular}{|c|c|c|c|c|c|c|c|c|c|c|c|c|c|}
\hline & $\begin{array}{l}\text { Density } \\
\mathrm{g} \mathrm{cm}^{-3}\end{array}$ & $\mathrm{pH}$ & $\begin{array}{l}\text { Cond. } \\
\mu \mathrm{S} \mathrm{cm}^{-1}\end{array}$ & $\begin{array}{c}\delta^{18} \mathrm{O} \\
\% 0\end{array}$ & $\begin{array}{c}\mathrm{F}^{-} \\
\mathrm{mg} \mathrm{L}^{-1}\end{array}$ & $\begin{array}{c}\mathrm{Cl}^{-} \\
\mathrm{mg} \mathrm{L}^{-1}\end{array}$ & $\begin{array}{l}\mathrm{NO}_{3}{ }^{-} \\
\mathrm{mg} \mathrm{L}^{-1}\end{array}$ & $\begin{array}{l}\mathrm{SO}_{4}{ }^{2-} \\
\mathrm{mg} \mathrm{L}^{-1}\end{array}$ & $\begin{array}{c}\mathrm{Na}^{+} \\
\mathrm{mg} \mathrm{L}^{-1}\end{array}$ & $\begin{array}{l}\mathrm{NH}_{4}^{+} \\
\mathrm{mg} \mathrm{L}^{-1}\end{array}$ & $\begin{array}{c}\mathrm{K}^{+} \\
\mathrm{mg} \mathrm{L}^{-1}\end{array}$ & $\begin{array}{l}\mathrm{Mg}^{2+} \\
\mathrm{mg} \mathrm{L}^{-1}\end{array}$ & $\begin{array}{l}\mathrm{Ca}^{2+} \\
\mathrm{mg} \mathrm{L}^{-1}\end{array}$ \\
\hline \multicolumn{14}{|c|}{ Median } \\
\hline Total & 0.72 & 6.53 & 9.80 & -8.41 & 0.11 & 0.42 & 0.09 & 0.26 & 0.33 & 0.06 & 0.15 & 0.02 & 1.04 \\
\hline $\mathrm{BOA}$ & 0.55 & 5.78 & 5.05 & -8.22 & 0.10 & 0.28 & 0.05 & 0.11 & 0.27 & 0.05 & 0.11 & 0.00 & 0.28 \\
\hline ВОВ & 0.73 & 6.63 & 11.60 & -8.59 & 0.10 & 0.43 & 0.12 & 0.38 & 0.34 & 0.06 & 0.16 & 0.02 & 1.46 \\
\hline BOC & 0.84 & 6.63 & 12.40 & -8.37 & 0.11 & 0.54 & 0.09 & 0.49 & 0.33 & 0.06 & 0.20 & 0.02 & 1.24 \\
\hline \multicolumn{14}{|l|}{ Mean } \\
\hline Total & 0.71 & 6.45 & 12.45 & -8.68 & 0.14 & 0.67 & 0.12 & 0.39 & 0.51 & 0.06 & 0.23 & 0.02 & 1.40 \\
\hline $\mathrm{BOA}$ & 0.61 & 6.03 & 8.52 & -8.33 & 0.17 & 0.75 & 0.08 & 0.23 & 0.62 & 0.05 & 0.23 & 0.01 & 0.65 \\
\hline BOB & 0.72 & 6.62 & 12.59 & -8.81 & 0.13 & 0.64 & 0.16 & 0.39 & 0.48 & 0.06 & 0.23 & 0.02 & 1.51 \\
\hline BOC & 0.81 & 6.77 & 17.33 & -8.96 & 0.12 & 0.61 & 0.11 & 0.58 & 0.41 & 0.08 & 0.22 & 0.04 & 2.22 \\
\hline
\end{tabular}

precipitation (Leuenberger, 2005). Temperature measurements, using a probe that was inserted into the core immediately after core extraction, produced values between $0.0^{\circ} \mathrm{C}$ and $-0.4^{\circ} \mathrm{C}$. The precipitation contains isotopes of oxygen and hydrogen which are correlated with air temperature at the time of deposition (Johnsen and others, 1997). Aerosol concentrations allow, inter alia, conclusions as to previous environmental conditions and the possibility of a chronological classification. However, during the summer period, ablation processes occur that can damage the deposition record considerably. It is almost certain that there are translocation processes due to percolating water during the melting process (Eichler and others, 2001). During the course of the rearrangement of ions at snow metamorphosis the substances that are less efficient wash out and undergo integration into the ice grid during grain growth.

As indicated by the conductivity measurements (Fig. 5c), the total ion concentration generally increases with depth (conductivity $<10 \mu \mathrm{S} \mathrm{cm}^{-1}$ in the old snow/firn, $10-20 \mu \mathrm{S} \mathrm{cm}^{-1}$ in the deeper firn/ice layers). This increase indicates relative matter enrichment (relative to volume, mass or bulk density; enrichment processes: translocation, evaporation, compaction). Individual layers near the base show conductivity peaks of $>60 \mu \mathrm{S} \mathrm{cm}^{-1}$. $\mathrm{pH}$ values (Fig. 5b) of 6.0-6.5 are found in the uppermost $3 \mathrm{~m}$. Below this, they decrease slightly, then increase with depth to values between 6.5 and 7.0.

At Snezhnika glacieret, calcium dominates as a rockdetermined ion (marble), whereas sulphate exhibits the highest concentration in firn and glacier features in siliceous areas (Eichler and others, 2001; Veit, 2002; Pohjola and others, 2005). Quantitatively, magnesium is usually at the end of the ion series. Compared with anions, cations quantitatively dominate in the Pirin Mountains (Table 2) and the total ion contents are considerably higher than in larger glaciers. The calcium ion concentration fluctuates by $1 \mathrm{mg} \mathrm{L}^{-1}$ to a depth of almost $10 \mathrm{~m}$ and increases at the base. However, the sulphate ion concentration decreases with depth in the BOC core. For most other ions, there are no clear trends, while single layers in different depths stand out because of peaks. Whether the latter could constitute marker horizons for dating purposes is yet to be clarified.

Isotope investigation of ice cores allows estimation of past climate. The $\delta^{18} \mathrm{O}$ analyses of the sampled layers of
Snezhnika glacieret, however, are only suitable to a limited degree in this regard because complete annual layers over timescales $>1$ year are likely to be deficient. There is a decreasing trend with depth of the isotope values in our cores (Fig. $5 \mathrm{~d}$ ). The lower $\delta^{18} \mathrm{O}$ values at the base may indicate cooler deposition conditions and older ice (Moser and Rauert, 1980).

Material from the BOC core from near the base $(9.75 \mathrm{~m}$ depth) was ${ }^{14} \mathrm{C}$ dated. Pollen was analysed; however, age could not be calibrated at the Accelerator Mass Spectronometry (AMS) Laboratory, Erlangen, Germany. Apparently the sample contained a mixture of material from before and after the 1955 bomb peak. Therefore, this ice could be $\sim 50 \pm 20$ years old. Organic material from $10.03 \mathrm{~m}$ deep in the BOC core was also dated. This sample was measured at a calibrated age of AD 1810-1924, but the result only allows statements as to the development period of the organic substance.

The moraines around the glaciers are characteristic of cirque moraines and provide interesting data on the former behaviour of the glaciers. Their dating gives important indications as to glacier advances. Moraine at Snezhnika glacieret was dug up and examined in September 2005 (Grunewald and Scheithauer, 2008d; Grunewald and others, 2009). Dark humus soil-like components $60-240 \mathrm{~cm}$ deep were noted in the moraine wall (Fig. 6). On the one hand, this is evidence for soil development at this altitude, yet on the other it shows relocation because such thickness cannot be developed in situ. A protalus rampart can be ruled out due to $2 \mathrm{~m}$ thick humus material in the moraine. The steepness of the outer wall and two-layered stratification of the frontal slope is characteristic of a rock glacier (on top of rocks, underneath finer material; Barsch, 1993). The debris underneath the glacieret gravitated in a frozen ice-rich state towards the wall. The results clearly confirm a moraine because it concerns coarse ungraded strangled material. The moraine is likely to mark the size of the glacier at the LIA maximum at approximately AD 1850 in Golemiya Kazan cirque (e.g. Grove, 2004).

The ${ }^{14} \mathrm{C}$ datings of the humus layers showed two soil genetic phases of surprisingly younger ages (calibrated ages: AD 330-610 and AD 1150-1270). A younger pressure on the wall can be assumed because the four analysed layers are stored in alternating ages. The chemical-physical results verify the dating of two different age layers (Fig. 6). 


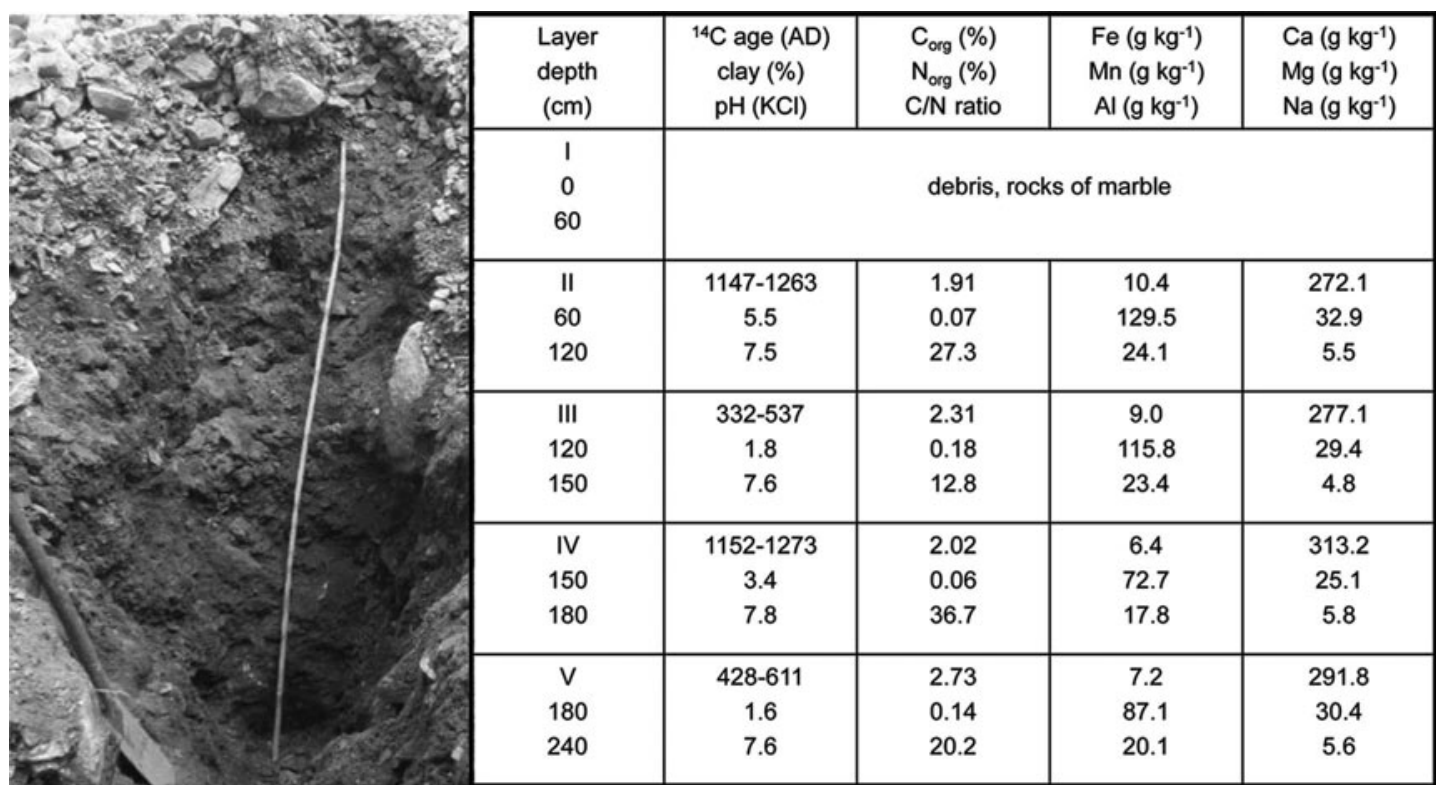
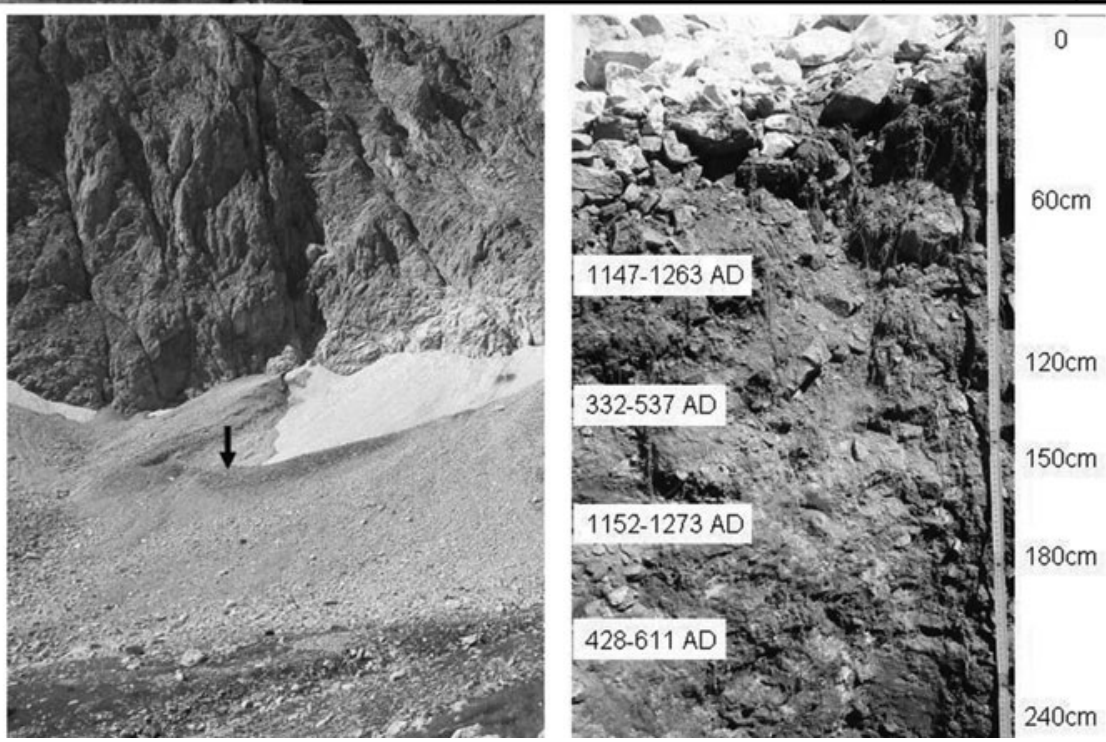

Fig. 6. Debris-covered moraine of Snezhnika glacieret (2430 m a.s.l.).

The soil ages determined at the AMS Laboratory refer to the soil organic matter (SOM) of the samples. The SOM should be generated, inter alia, by root material and to a lesser extent by decomposed litter at this altitude. According to Trumbore and Zheng (1996), the SOM age is slightly greater than the ${ }^{14} \mathrm{C}$ age. Although the composition of the SOM was not investigated and the age has to be interpreted carefully, the finding is an indicator of changing climatic conditions.

Further dating of soil, peat and lake sediments $\left({ }^{14} \mathrm{C}\right.$ dating of humus and charcoal) at Malkija Kazan cirque and at the timberline ecotone in the northern Pirin Mountains verifies the soil development intervals (Grunewald and Scheithauer, 2008b; Grunewald and others 2009). Warmer periods during Roman times and in early medieval times might have enabled geomorphological stability and development of plants and soils under ice-free conditions in the range of the present glacieret. When subjected to regular frost, soil genesis stagnates (Eitel, 1999) and cryogenic processes dominate. Consequently, the moraine development probably took place under colder conditions between AD 1270 and approximately AD 1850.

Hughes (2007) examined front moraines using lichenometric methods (Aspicilia calcerea agg.) at Debeli Namet glacier. The dating produced three ages: AD 1878, AD 1904 and a younger activity (1994-2005). Hughes (2007) hence deduced periods with cooler summers between 1875 and 1925, which correspond well with the proxy data for the Alps (Wilson and others, 2005) and the Mediterranean (Repapis and Philandras, 1988). However, precipitation could also be an important factor. According to Katsoulis and Kambezidis (1989), precipitation was particularly high in the southern Balkans during the decade 1875-84. On the other hand, the period between 1850 and 1870 was, at least in the Alps, extremely dry (R. Böhm and others, http:// www.zamg.ac.at).

In the case of all climate reconstructions based on former glacier variations, several methods should be used for validation, i.e. morphogenetic phases known in the cirques should be checked against historical sources and 


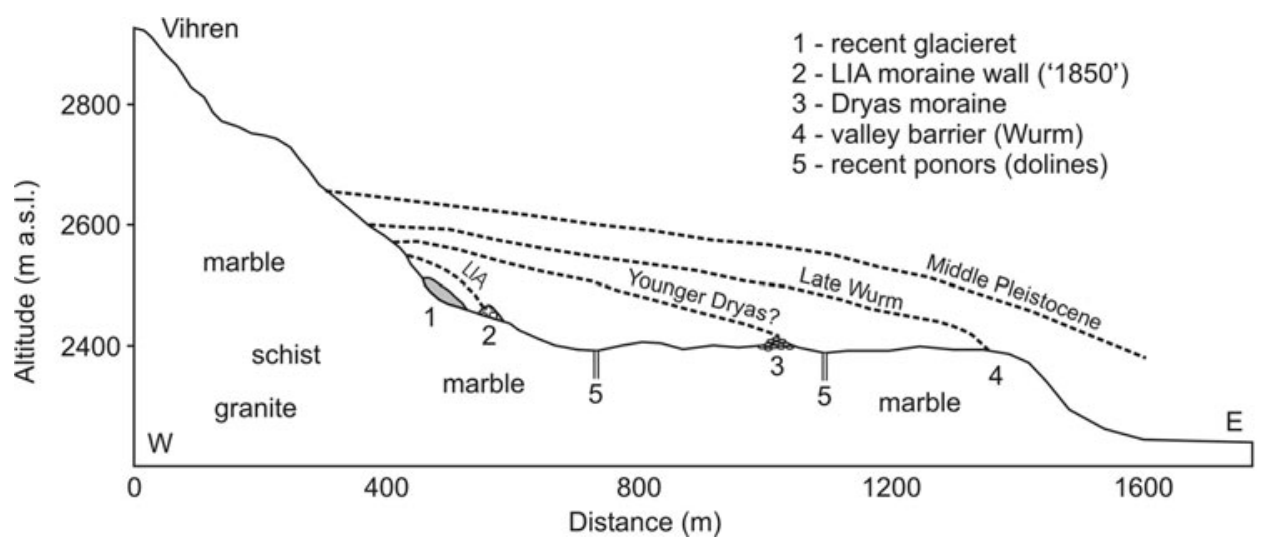

Fig. 7. Simplified profile of the glacier positions on a scale of millennia in Golemiya Kazan cirque in the northern Pirin Mountains, Bulgaria. (glacier extents estimated after Popov, 1962)

independent physical records such as lichenometry, dendroclimatology and historical climatology.

\section{RESPONSE OF SMALL GLACIERS TO CLIMATE CHANGE}

Glacial geomorphological records offer evidence of palaeoclimatic conditions in high mountains during the Quaternary in southern Europe (e.g. Cacho and others, 2002; Garcia-Ruiz and others, 2003; Alberti and others, 2004; Woodward and others, 2004; Kuhlemann and others, 2005). Figure 7 shows the estimated glacier fluctuations of Golemiya Kazan cirque in the Pirin Mountains. The most extensive phases of glaciation were probably during the middle Pleistocene (Hughes and others, 2007; Kuhlemann and others, 2008). In Greece, Italy and Spain the glacial deposits of middle Pleistocene age were specified by radiometric dating (Hughes and others, 2006b). The glacial succession in Greece was dated by Hughes and others (2006a) who applied U-series methods to date secondary carbonates within Pleistocene tills to develop a new regional geochronology and chronostratigraphy. This evidence provided the basis for palaeoclimatic reconstructions for different glaciations. Hughes and others (2007) analysed the lowest mean summer temperatures during 474000 427000 BP (middle Pleistocene), which caused the most extensive glaciations recorded in the Mediterranean region. Later Pleistocene glaciations were characterized by higher summer temperatures and higher annual precipitation, resulting in less glaciation (Vlasian stage and Tymphian stage of the Pindus chronostratigraphy; Hughes and others, 2007). In other regions, detailed sedimentological and pedological analyses of glacial and fluvioglacial sediments are needed to supplement the numerical dating methods (e.g. in other Balkan mountains (Milivojevič and others, 2008)).

The glaciation of the region during the Last Glacial Maximum ( $\left.\sim 20000-18000{ }^{14} \mathrm{C} \mathrm{BP}\right)$ resulted in approximately half the glacier extension during the middle Pleistocene (Popov, 1962; Kuhlemann and others, 2008). Except for the Pyrenees, the Wurmian glaciers in southern Europe were limited to a few high-altitude cirques (Messerli, 1967), which melted relatively quickly with the onset of warming. However, during the late Wurm, fossil, secondary, lobed cirque glaciers and/or rock glaciers must still have been situated in cirques such as Golemiya Kazan (Grunewald and Scheithauer, 2008c).

The Holocene has been a period of remarkable climatic stability in which temperatures have varied within a small range of $\pm 2{ }^{\circ} \mathrm{C}$ (Solomon and others, 2007). The climate variability for the last $\sim 15000$ years can be described with the help of cirque lake sediments, peat bog profiles and fossil soil developments/charcoal (Grunewald and Scheithauer, 2008d). The Pirin Mountains region is well researched in this regard (e.g. Bozilova and Tonkov, 2000; Tonkov and others, 2002; Stefanova and Ammann, 2003; Stefanova and others, 2006). It is certain that all smaller southern glaciers melted at the climate optimum of the Atlantic Period. The reconstruction of the Alpine timberline implies that the snowline during the Holocene did not change significantly (Grunewald and Scheithauer, 2008d).

During the LIA (beginning AD 1300-1550, end AD 18501860), the glaciers of southern Europe re-formed or advanced (Maisch and others, 1999a; Federici and Stefanini, 2001; Grove, 2004; González Trueba and others, 2008) and this interval was a significant climatic event for geomorphology and culture in this region (Grove, 2001; Grunewald and Scheithauer, 2008b). Glacier studies and the investigation of further geo-archives in the Pyrenees, Apennines and the Balkans or in the Alps provide information about local and regional climate variations during the LIA. Young loosely bedded moraines are the definite result of glacier advances (Figs 2 and 6) and the current glaciers of southern Europe are relics of this cold Holocene era.

The glaciers in the Pyrenees reached dimensions of up to $2.36 \mathrm{~km}^{2}$ during the LIA (e.g. Aneto glacier; (Gonzáles Trueba and others, 2008)). Glaciers were much smaller in other mountains in Spain (e.g. $0.03 \mathrm{~km}^{2}$ in Picos de Europa), in the Apennines and on the Balkan Peninsula. The glacierclimate relation of the LIA has been examined with high resolution for the Alps (e.g. Fagan, 2000), and the main stages are also known for the Spanish mountains (Chueca and others, 2007; Gonzáles Trueba and others, 2008). In Figure 8 the four main phases of Iberia are opposed to the dynamics of the Alpine glaciers and furthermore the reconstructed temperatures in southeastern Europe (Pirin Mountains) are listed (Grunewald and Scheithauer, 2008c). A high temporal resolution of the climate conditions during the LIA in southern European mountains is only attainable with dendrological investigations, whereas glacier deposits 


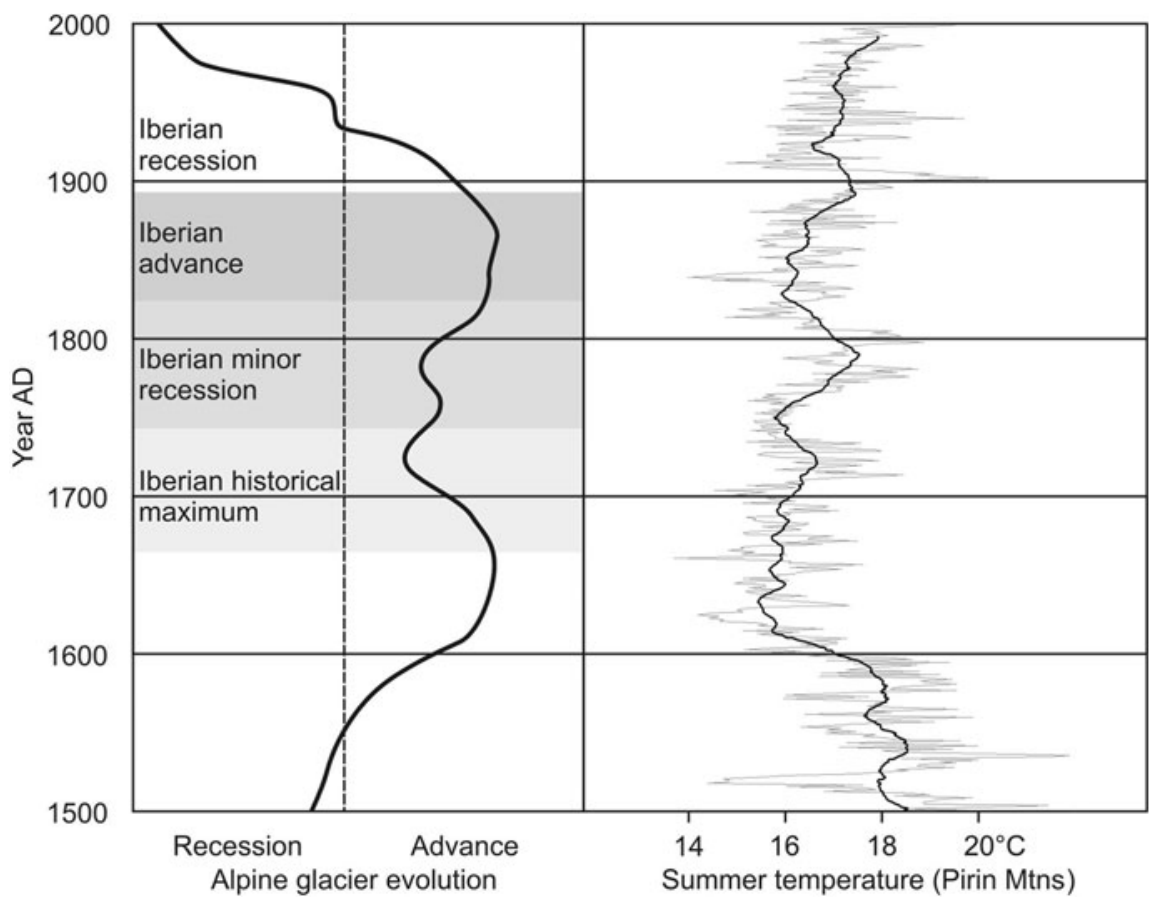

Fig. 8. Alpine glacier evolution (after Fagan, 2000), Iberian LIA stages (Gonzáles Trueba and others, 2008) and reconstructed temperatures of the Pirin Mountains during the LIA (dendrochronology of Pinus heldreichii; Grunewald and Scheithauer, 2008c).

solely trace the main phases when ice advanced or stabilized.

The synchronism of cold and warm phases is astonishing (Fig. 8). There is a sharp temperature decline at AD 1600, which implies the beginning of the main phase of the LIA. The climate of the following period is determined by mean summer temperatures which are nearly $2-3^{\circ} \mathrm{C}$ lower. Soil genesis processes, which were observed in the sub-Alpine sites of the Pirin Mountains, came to a halt, along with a descended climatic snowline, a shorter vegetation period and a longer snow cover (Grunewald and Scheithauer, 2008c).

Smaller southern glaciers probably existed for the first time during the early 17 th century. Charcoal findings in soils in many partly overlapped layers at the sub-Alpine timberline in the Pirin Mountains (Grunewald and Scheithauer, 2008b) mark the beginning of a morphologically more active phase with evidence of an increased occurrence of weather extremes. The overall relatively cold period was repeatedly interrupted by milder phases, such as $1718-29$ or 1775-1800; these phases are known as favourable years (Veit, 2002). After AD 1800 the second temperature decrease period began which lasted about 50 years (Fig. 8). From the second half of the 19th century onwards, it then became warmer and more consistent.

During the course of the 20th century, a temperature increase of up to $1^{\circ} \mathrm{C}$ was observed in many places such as in Bulgaria and Spain (Gonzáles Trueba and others, 2008; Grunewald and Scheithauer, 2008c). The glaciers have responded to the significant warming; some of the southernmost glaciers such as Corral del Veleta quickly disappeared. The pace of the retreat is a function of initial size (LIA maximum), local climate and geofactors (i.e. slope, aspect, topography). The annual snow/firn balance depends particularly on the amount of accumulated winter precipitation and avalanche/snow blown catchment as well as on summer temperatures and warm summer rainfall (Ohmura and others, 1992; Grunewald and others, 2006; Hughes, 2008).

Between phases of glacier retreat, glaciers temporarily stabilized. These periods of stabilization correspond with colder phases that were observed in Spain and Bulgaria and correlate with the Alpine glacier readvances in the 1890s, 1920s and 1970-80 (Patzelt, 1985; Chueca and others, 2007; Zemp and others, 2007; Grunewald and others, 2009).

Nevertheless, overall glacier retreat was characteristic of the last $\sim 150$ years. Europe's southernmost glaciers have lost relatively moderate surface area but significantly more in volume. For example, Ghiacciaio del Calderone has lost half of its surface between 1794 and 1990 but $92 \%$ of its volume (D'Alessandro and others, 2001). The Pyrenean glaciers have lost $84 \%$ of their extension between 1894 and 2001 (Gonzáles Trueba and others, 2008). The Alpine glaciers have lost half of their surface between 1850 and 2000, but two-thirds of their volume (Zemp and others, 2007). In a northern European region like Jotunheimen, Norway, the glacier recession since the LIA has been only one-third (Andreassen and others, 2008).

Since the 1980s, a significant temperature increase is observed in all study regions in southern Europe (e.g. the Alps), and record temperatures have been reported repeatedly in the last two decades (e.g. R. Böhm and others, http:// www.zamg.ac.at; Chueca and others, 2007; Citterio and others, 2007; Grunewald and others, 2009). For instance, 2003 was the hottest year of the last 500 years in Europe (Luterbacher and others, 2004); in Montenegro, 2007 was even warmer (Hughes, 2008). Grunewald and others (2009) reported a 'new temperature level' in the southwestern Bulgarian mountains at the end of the 1990s and a longer vegetation period, local droughts in spring and autumn and an increase of frost-change days at the timberline. 
The smaller southern glaciers respond quickly and in whole to extreme weather phases. Measurements at Snezhnika glacieret give examples of the accumulation and melt behaviour. Below the Vichren summit is a plateau area, and snow accumulations from this plateau are carried onto the glacier at the bottom of the cirque cliffs and contribute significant amounts of accumulation to the glacier mass balance. Whereas typical snow depths constitute $\sim 2 \mathrm{~m}$ on the cirque in April (measured with stakes in April 2001, 2003 and 2005), they reach $>10 \mathrm{~m}$ at Snezhnika glacieret (estimated at the face above). Popov (1964) determined loss rates of $104 \mathrm{~cm}\left(1.4 \mathrm{~cm} \mathrm{~d}^{-1}\right)$ between 16 and 30 September 1957. We determined melt rates of up to $7 \mathrm{~cm} \mathrm{~d}^{-1}$ in the lower part of the glacieret between 6 August and 9 September 2004, measured using five stakes (Grunewald and others, 2006).

If warm summers follow winters with few snowfalls over several years, the glaciers and glacierets shrink until they reach a new equilibrium mass balance or melt completely. This was established for the Balkan Peninsula (also High Tatra), for example, in 1994 (Litwin, 1997; Nadbath, 1999; Grunewald and others, 2006; Hughes, 2007). Glaciers survived individual summers such as 2003 and 2007 although they experienced significant retreat. Phases with above-average winter precipitation and cooler summers are often sufficient to stabilize small glaciers or even produce readvance. At Debeli Namet glacier, for example, a new moraine even developed between 1994 and 2003, and between 2004 and 2006, due to small glacier advances (Hughes, 2007, 2008). Debris for moraine formation is likely to be enhanced by the large area of debris-supplying rock walls and this may explain the production of very large late 19th-century and early 20th-century moraines yet small glacier size (Maisch and others, 1999b; Zemp and others, 2005; Hughes, 2008).

Chueca and others (2007) examined the recent evolution (1981-2005) of the Maladeta glaciers in Spain and their relation to climatic factors. Precipitation during the accumulation period decreased significantly, reducing the snowfall contribution to mean balance in February and March. In addition, an increase in temperature during the ablation season, in particular the maximum temperature, was observed. This is the main reason for the surface and volumetric shrinkage registered on all glaciers. There are no reports of stabilization phases in the recent past in the Iberian region.

Overall, it is typical that during the recent final step of a glacial degradation process in southern Europe, the relative influence of climatic factors decreases as the influence of topographic and other geofactors (Fig. 3) increases (LópezMoreno and others, 2006; Zemp and others, 2006).

\section{CONCLUSION}

The southern European mountains have received scant attention in the literature. However, numerous small glaciers, glacierets and perennial snow/firn patches exist in several mountain areas such as in Spain, southern France, Italy, Montenegro and Bulgaria - the focus of this study. Recently there has been a research interest in these small glaciers, which are the southernmost glaciers in Europe, excluding those of the Caucasus.

Analysis of three ice cores drilled on Snezhnika glacieret in September 2006 revealed possibilities and limits to the study of these small glaciers. Core drilling with the Ruefli driller was technically very successful. Plausible depth profiles of $\sim 11 \mathrm{~m}$ could be obtained. The ion concentrations of the glacierets were relatively high, and dating of material from the base indicated an ice age of 50-100years. However, annual long-term climate information was not obtainable because of intermittent layers or percolating meltwater which modifies the climate signals (Grunewald and Scheithauer, 2008a).

The investigations were supplemented and substantiated by studies in the glacier's surroundings. Thick humus developments in the moraines around the glacierets indicate changing climatic conditions. Warmer periods with vegetation and soil development must have alternated with cooler periglacial conditions. In the Pirin Mountains these warmer phases during which glacierets and firn patches barely existed were probably at approximately AD 300-600 and AD 1100-1300. The moraine features around the glacieret represent the maximum of the LIA glaciation in the area.

Regional comparison of glaciers of Atlantic-Mediterranean characteristic (Iberian Peninsula) with those of PonticMediterranean characteristic (Balkan Peninsula) shows many similarities concerning glacier types and geofactors as well as climate-glacier phases. Climate change appears to take place with a similar intensity at the scale from millennia to centuries in the investigated regions, even though the characteristics of single years and seasons are regionally differentiated. New results from glacier environments in the Balkans closely correlate with these climatic changes.

There has been a temperature increase of $\sim 1^{\circ} \mathrm{C}$ since the LIA in many investigated areas (e.g. Pirin Mountains (Grunewald and Scheithauer, 2008c); Pyrenees (Gonzáles Trueba and others, 2008)) and for this reason southern European glaciers have retreated. This tendency for climate warming has intensified in recent years. However, small glaciers appear to survive such warming, largely because of local topoclimatic influences. The dominance of local climate effects on accumulation and ablation, such as avalanching and shading, is likely to insulate them from the effects of regional climate. Thus, even at higher temperatures these glaciers are likely to persist, until of course a threshold is reached when local climate controls are unable to sustain glacier survival.

A further temperature increase by $1.1-6.4^{\circ} \mathrm{C}$ in the $21 \mathrm{st}$ century, as predicted by Solomon and others (2007), anticipates the following scenario estimation for all southern glaciers in Europe $\left(<44^{\circ} \mathrm{N}\right)$ : they will melt and disaggregate in situ. The old ice relics of the LIA at the base of these glaciers will also disappear. Thus, the environmental information stored in this ice will be lost. Glacier retreat will result in opportunities for pioneer plant and soil development over the former glacier sites, and permafrost is likely to become rarer. In future, however, increasing winter precipitation is likely to result in greater snow accumulation. In the short term, this snow accumulation may exceed snow mass lost by summer ablation so that, at protected sites, snow/firn patches may dominate in the Pyrenees and the Balkans.

\section{ACKNOWLEDGEMENTS}

The studies were realized with the support of the German Research Foundation DFG (funding number: GR 1432/11), 
as well as in cooperation with the administration of Pirin National Park. We thank P.D. Hughes for editing the text, C. Weber, T. Wieloch and A. Hennig for assistance with drilling and sampling, and reviewers for helpful comments.

\section{REFERENCES}

Alberti, A.P., M.V. Diaz and R.B. Chao. 2004. Pleistocene glaciation in Spain. In Ehlers, J. and P.L. Gibbard, eds. Quaternary glaciations - extent and chronology. Part I: Europe. Amsterdam, etc., Elsevier. (Developments in Quaternary Science 2.)

Andreassen, L.M., F. Paul, A. Kääb and J.E. Hausberg. 2008. Landsat-derived glacier inventory for Jotunheimen, Norway, and deduced glacier changes since the 1930s. Cryosphere, 2(2), 131-145.

Barsch, D. 1993. Schneehaldenmoränen (Protalus Ramparts): ein falsches Modell behindert die päläoklimatische Deutung. Würz. Geogr. Arb., 87, 257-267.

Bozilova, E.D. and S.B. Tonkov. 2000. Pollen from Lake Sedmo Rilsko reveals southeast European postglacial vegetation in the highest mountain area of the Balkans. New Phytol., 148(2), 315-325.

Büdel, J. 1949. Die räumliche und zeitliche Gliederung des Eiszeitklimas. Naturwissenschaften, 36(4), 105-112.

Cacho, I., J.O. Grimalt and M. Canals. 2002. Response of the Western Mediterranean Sea to rapid climatic variability during the last 50,000 years: a molecular biomarker approach. J. Mar. Syst., 33-34, 253-272.

Chen, J. and A. Ohmura. 1990. Estimation of Alpine glacier water resources and their change since the 1870s. IAHS Publ. 193 (Symposium at Lausanne 1990 - Hydrology in Mountainous Regions), 127-135.

Chueca, J., A. Julián and J.I. López-Moreno. 2007. Recent evolution (1981-2005) of the Maladeta glaciers, Pyrenees, Spain: extent and volume losses and their relation with climatic and topographic factors. J. Glaciol., 53(183), 547-557.

Citterio, M. and 6 others. 2007. The fluctuations of Italian glaciers during the last century: a contribution to knowledge about Alpine glacier changes. Geogr. Ann., Ser. A, 89(3), 167-184.

D'Alessandro, A., M. D'Orefice, M. Pecci, C. Smiraglia and R. Ventura. 2001. The strong reduction phase of the Calderone glacier during the last two centuries: reconstruction of the variation and of the possible scenarios with GIS technologies. In Visconti, G., M. Beniston, E.D. Iannorelli and D. Barba, eds. Global change and protected areas. Dordrecht, Kluwer, 425-433.

D'Orefice, M., M. Pecci, C. Smiraglia and R. Ventura. 2000. Retreat of Mediterranean glaciers since the Little Ice Age: case study of Ghiacciaio del Calderone, central Apennines, Italy. Arct. Antarct. Alp. Res., 32(2), 197-201.

Eichler, A., M. Schwikowski and H.W. Gäggeler. 2001. Meltwaterinduced relocation of chemical species in Alpine firn. Tellus, 53B(2), 192-203.

Eitel, B. 1999. Bodengeographie. Braunschweig, Westermann.

Fagan, B. 2000. The Little Ice Age: how climate made history 1300 1850. New York, Basic Books.

Federici, P.R. and M. Pappalardo. 1996. L'evoluzione recente dei ghiacciai delle Alpi Maritime. Geogr. Fís. Din. Quat., 18(2), 257-269.

Federici, P.R. and M.C. Stefanini. 2001. Evidence and chronology of the Little Ice Age in the Argentera Massif (Italian Maritime Alps). Z. Gletscherkd. Glazialgeol., 37, 35-48.

Finsinger, W. and A. Ribolini. 2001. Late glacial to Holocene deglaciation of the Colle del Vei del Bouc-Colle del Sabbione area (Argentera Massif, Maritime Alps, Italy-France). Geogr. Fís. Din. Quat., 24(2), 141-156.
Gabrovec, M. 1998. Triglavski ledenik med letoma 1986 in 1998 [The Triglav glacier between 1986 and 1998]. Geogr. Zbornik, 38, 89-105.

Gądek, B. and A. Kotyrba. 2003. Struktura wewnátrzna Lodowczyka Miáguszowieckiego (Tatry) w éwietle wynik'w badaé georadarowych. Prz. Geol., 51(12), 1044-1047.

Gams, I. 1994. Changes of the Triglav glacier in the 1955-94 period in the light of climatic indicators. Geogr. Zbornik, 34, 81-117.

García-Ruiz, J.M., B.L. Valero-Garcés, C. Martí-Bono and P. González-Sampériz. 2003. Asynchroneity of maximum glacier advances in the central Spanish Pyrenees. J. Quat. Sci. 18(1), 61-72.

Gellatly, A.F., C. Smiraglia, J.M. Grove and R. Latham. 1994. Recent variations of Ghiacciaio del Calderone, Abruzzi, Italy. J. Glaciol., 40(136), 486-490.

Giraudi, C. 2005. Middle to Late Holocene glacial variations, periglacial processes and alluvial sedimentation on the higher Apennine massifs (Italy). Quat. Res., 64(2), 176-184.

Gómez Ortiz, A., D. Palacios, M. Ramos, L.M. Tanarro, L. Schulte and F. Salvador. 2001. Location of permafrost in marginal regions: Corral del Veleta, Sierra Nevada, Spain. Permafrost Periglac. Process., 12(1), 93-110.

González Trueba, J.J. 2006. Topoclimatical factors and very small glaciers in atlantic mountain of SW Europe: the Little Ice Age glacier advance in Picos de Europa (NW Spain). Z. Gletscherkd. Glazialgeol., 39, 115-125.

González Trueba, J.J., R. Martín Moreno, E. Martínez de Pisón and E. Serrano. 2008. 'Little Ice Age' glaciation and current glaciers in the Iberian Peninsula. Holocene, 18(4), 551-568.

Grove, A.T. 2001. The 'Little Ice Age' and its geomorphological consequences in Mediterranean Europe. Climatic Change, 48(1), 121-136.

Grove, J.M. 2004. Little ice ages: ancient and modern. Second edition. London and New York, Routledge.

Grunewald, K. and J. Scheithauer. 2008a. Bohrung in einen Mikrogletscher. Z. Gletscherkd. Glazialgeol., 42(1), 3-18.

Grunewald, K. and J. Scheithauer. 2008b. Holocene climate and landscape history of the Pirin Mountains (southwestern Bulgaria). In Borsdorf, A., J. Stötter and E. Veulliet, eds. Managing Alpine future: proceedings of the Innsbruck Conference, 1517 October 2007. Vienna, Österreichische Akademie der Wissenschaften, 305-312. (IGF-Forschungsberichte, Band 2.)

Grunewald, K. and J. Scheithauer. 2008c. Klima- und Landschaftsgeschichte Südosteuropas: Rekonstruktion anhand von Geoarchiven im Piringebirge (Bulgarien). Berlin, Rhombos. (Beiträge zur Landschaftsforschung 6.)

Grunewald, K. and J. Scheithauer. 2008d. Untersuchungen an der alpinen Waldgrenze im Piringebirge (Bulgarien). Geo-Öko, 29(1-2), 1-32.

Grunewald, K. and D. Stoilov. 1998. Natur- und Kulturlandschaften Bulgariens: Landschaftsökologische Bestandsaufnahme, Entwicklungs- und Schutzpotential. Marburg, Biblion. (Bulgarische Bibliothek Neue Folge 3.)

Grunewald, K., C. Weber, J. Scheithauer and F. Haubold. 2006. Mikrogletscher im Piringebirge (Bulgarien). Z. Gletscherkd. Glazialgeol., 39, 99-114.

Grunewald, K., J. Scheithauer and A. Gikov. 2008. Mikrolednitzi v Pirin Planina [Microglaciers in the Pirin Mountains, Bulgaria]. Probl. Geogr., 1-2, 164-180.

Grunewald, K., J. Scheithauer, J.-M. Monget and D. Brown. 2009. Characterisation of contemporary local climate change in the mountains of southwest Bulgaria. Climatic Change, 95(3-4), 535-549.

Hughes, P.D. 2007. Recent behaviour of the Debeli Namet glacier, Durmitor, Montenegro. Earth Surf. Process. Landf., 32(10), 1593-1602.

Hughes, P.D. 2008. Response of a Montenegro glacier to extreme summer heatwaves in 2003 and 2007. Geogr. Ann., Ser. A, 90(4), 259-267. 
Hughes, P.D. 2009. Twenty-first century glaciers and climate in the Prokletije Mountains, Albania. Arct. Antarct. Alp. Res., 41(4), 455-459.

Hughes, P.D. and J. Woodward. 2009. Glacial and periglacial environments. In Woodward, J., ed. The physical geography of the Mediterranean. Oxford, etc., Oxford University Press.

Hughes, P.D., J.C. Woodward, P.L. Gibbard, M.G. Macklin, M.A. Gilmour and G.R. Smith. 2006a. The glacial history of the Pindus Mountains, Greece. J. Geol., 114(4), 413-434.

Hughes, P.D., J.C. Woodward and P.L. Gibbard. 2006b. Quaternary glacial history of the Mediterranean mountains. Progr. Phys. Geogr., 30(3), 334-364.

Hughes, P.D., J.C. Woodward and P.L. Gibbard. 2007. Middle Pleistocene cold stage climates in the Mediterranean: new evidence from the glacial record. Earth Planet. Sci. Lett. 253(1-2), 50-56.

Jania, J. 1997. The problem of Holocene glacier and snow patches fluctuations in the Tatra Mountains: a short report. In Frenzel, B., G.S. Boulton, B. Gläser and U. Huchriede, eds. Glacial fluctuations during the Holocene. Jena, Gustav Fischer, 85-93. (Paläoklimaforschung 24.)

Johnsen, S.J. and 14 others. 1997. The $\delta^{18} \mathrm{O}$ record along the Greenland Ice Core Project deep ice core and the problem of possible Eemian climatic instability. J. Geophys. Res., 102(C12), 26,397-26,410.

Kaser, G. 2001. Glacier-climate interaction at low latitudes. J. Glaciol., 47(157), 195-204.

Katsoulis, B.D. and H.D. Kambetzidis. 1989. Analysis of the longterm precipitation series at Athens, Greece. Climatic Change, 14(3), 263-290.

Kuhlemann, J., W. Frisch, B. Székely, I. Dunkl, M. Danišík and I. Krumrei. 2005. Würmian maximum glaciation in Corsica. Austrian J. Earth Sci., 97, 68-81.

Kuhlemann, J., E. Gachev, A. Gikov and S. Nedkov. 2008. Glacial extent in the Rila Mountain (Bulgaria) as part of an environmental reconstruction of the Mediterranean during the Last Glacial Maximum (LGM). Probl. Geogr., 3-4, 61-70.

Leuenberger, M. 2005. Stabile Isotope in polaren Eisbohrkernen enthalten klimarelevante Information. In Auf Spurensuche in der Natur: stabile Isotope in der ökologischen Forschung. München, Pfeil, 29-44. (Rundespräche der Kommission für Ökologie 30.)

Litwin, L. 1997. A study of perennial snow patches in the Slovak High Tatras: preliminary results. Geogr. Casopis, 49(2), 79-90.

Louis, H. 1933. Die eiszeitliche Schneegrenze auf der Balkanhalbinsel. Mitt. Bulg. Geogr. Ges., 1, 22.

López-Moreno, J.I., D. Nogués, J. Chueca and A. Julián. 2006. Glacier development and topographic context. Earth Surf. Process. Landf., 31(12), 1585-1594.

Luterbacher, J., D. Dietrich, E. Xoplaki, M. Grosjean and $\mathrm{H}$. Wanner. 2004. European seasonal and annual temperature variability, trends, and extremes since 1500. Science, 303(5663), 1499-1503.

Maisch, M., A. Wipf, B. Denneler, J. Battaglia and C. Benz. 1999a. Die Gletscher der Schweizer Alpen: Gletscherhochstand 1850 Aktuelle Vergletscherung - Gletscherschwund-Szenarien 21. Jahrhundert. Zürich, vdf Hochschulverlag AG an der ETH. (Schlussbericht NFP 31.)

Maisch, M., W. Haeberli, M. Hoelzle and J. Wenzel. 1999b. Occurrence of rocky and sedimentary glacier beds in the Swiss Alps as estimated from glacier-inventory data. Ann. Glaciol., 28 231-235

Marino, A. 1992. Nota preliminare sul fenomeno glaciologico della Grotta del Gelo (Monte Etna). Geogr. Fís. Din. Quat., 15 127-132

Meier, M.F., M.B. Dyurgerov and G.J. McCabe. 2003. The health of glaciers: recent changes in glacier regime. Climatic Change, 59(1-2), 123-135.

Messerli, B. 1967. Die eiszeitliche und die gegenwärtige Vergletscherung im Mittelmeeraum. Geogr. Helv., 22(3), 105-228.
Messerli, B. 1980. Mountain glaciers in the Mediterranean area and in Africa. IAHS Publ. 126 (Workshop at Riederalp 1978 - World Glacier Inventory), 197-211.

Milivojevič, M., L. Menkovič and J. Calič. 2008. Pleistocene glacial relief of the central part of Mt. Prokletije (Albanian Alps). Quat. Int., 190(1), 112-122.

Moser, H. and W. Rauert. 1980. Isotopenmethoden in der Hydrologie. Berlin, etc., Gebrüder Bortraeger.

Nadbath, M. 1999. Triglavski ledenik in spremembe podnebja [The Triglav Glacier and climate variations]. Ujma, 13, 24-29.

Ohmura, A., P. Kasser and M. Funk. 1992. Climate at the equilibrium line of glaciers. J. Glaciol., 38(130), 397-411.

Pappalardo, M. 1999. Remarks upon the present-day condition of the glaciers in the Italian Maritime Alps. Geogr. Fis. Din. Quat., 22(1), 79-82.

Paschinger, H. 1955. Die würmeiszeitliche Schneegrenze im Mittelmeergebiet. Mitt. Geol. Ges. Wien, 48, 201-205.

Patzelt, G. 1985. The period of glacier advances in the Alps: 1965 to 1980. Z. Gletscherkd. Glazialgeol., 21, 403-407.

Pavšek, M. 2004. The Skuta glacier. Geogr. Zbornik, 51, 11-17.

Pecci, M., G. De Sisti, A. Marino and C. Smiraglia. 2001. New radar surveys in monitoring the evolution of Ghiacciaio del Calderone (Central Apennines, Italy). Suppl. Geogr. Fis. Din. Quat., 5, 145-150.

Pohjola, V.A., J. Cole-Dai, G. Rosqvist, A.P. Stroeven and L.G. Thompson. 2005. Potential to recover climatic information from Scandinavian ice cores: an example from the small ice cap Riukojietna. Geogr. Ann., Ser. A, 87(1), 259-270.

Popov, V. 1962. Morphologija na Zirkusa Golemija Kasan v Pirin Planina [Morphology of the cirque 'Golemija Kasan', Pirin Mountains]. Sofia, Bulgarian Academy of Science, Institute of Geography.

Popov, V. 1964. Nabljudenia virchu sneshnika v zirkusa Golemija Kasan Pirin Planina [Conditions of the cirque 'Golemija Kasan', Pirin Mountains]. Sofia, Bulgarian Academy of Science, Institute of Geography.

Repapis, C.C. and C.M. Philandras. 1988. A note on the air temperature trends of the last 100 years as evidenced in the eastern Mediterranean time series. Theor. Appl. Climatol., 39(2), 93-97.

Roth von Telegd, K. 1923. Das albanisch-montenegrinische Grenzgebiet bei Plav (Mit besonderer Berücksichtigung der Glazialspuren). In Nowack, E., ed. Beiträge zur Geologie von Albanien. Stuttgart, E. Schweizerbart, 422-494. (Neues Jahrbuch für Mineralogie, Geologie und Paläontologie 1.)

Solomon, S. and 7 others, eds. 2007. Climate change 2007: the physical science basis. Contribution of Working Group I to the Fourth Assessment Report of the Intergovernmental Panel on Climate Change. Cambridge, etc., Cambridge University Press.

Stahr, A. and T. Hartmann. 1999. Landschaftsformen und Landschaftselemente im Hochgebirge. Berlin, etc., Springer-Verlag.

Stefanova, I. and B. Ammann. 2003. Lateglacial and Holocene vegetation belts in the Pirin Mountains (southwestern Bulgaria). Holocene, 13(1), 97-107.

Stefanova, I., J. Atanassova, M. Delcheva and H.E. Wright. 2006. Chronological framework for the Lateglacial pollen and macrofossil sequence in the Pirin Mountains, Bulgaria: Lake Besbog and Lake Kremensko-5. Holocene, 16(6), 877-892.

Tonkov, S., H. Panovska, G. Possnert and E. Bozilova. 2002. The Holocene vegetation history of Northern Pirin Mountain, southwestern Bulgaria: pollen analysis and radiocarbon dating of a core from Lake Ribno Banderishko. Holocene, 12(2), 201-210.

Trumbore, S.E. and S. Zheng. 1996. Comparison of fractionation methods for soil organic matter ${ }^{14} \mathrm{C}$ analysis. Radiocarbon, 38(2), 219-229.

UNESCO/International Association of Scientific Hydrology (IASH) 1970. Perennial ice and snow masses: a guide for compilation and assemblage of data for a world inventory. Paris, UNESCO/ IASH. (Technical Papers in Hydrology 1.) 
Veit, H. 2002. Die Alpen: Geoökologie und Landschaftsentwicklung. Stuttgart, Ulmer. (Uni-Taschenbücher 2327.)

Wilson, R., D. Frank, J. Topham, K. Nicolussi and J. Esper. 2005. Spatial reconstruction of summer temperatures in Central Europe for the last 500 years using annually resolved proxy records: problems and opportunities. Boreas, 34(4), 490-497.

Woodward, J.C., M.G. Macklin and G.R. Smith. 2004. Pleistocene glaciations in the mountains of Greece. In Ehlers, J. and P.L. Gibbard, eds. Quaternary glaciations: extent and chronology, Part I: Europe. 155-173. (Developments in Quaternary Sciences 2.)

World Glacier Monitoring Service (WGMS). 2008. Fluctuations of glaciers 2000-2005 (Vol. IX), ed. W. Haeberli, M. Zemp,
A. Kääb, F. Paul and M. Hoelzle. ICSU/IUGG/UNEP/UNESCO/ WMO, World Glacier Monitoring Service, Zürich.

Zemp, M., A. Kääb, M. Hoelzle and W. Haeberli. 2005. GIS-based modelling of glacial sediment balance. Z. Geomorphol., 138, 113-129.

Zemp, M., W. Haeberli, M. Hoelzle and F. Paul. 2006. Alpine glaciers to disappear within decades? Geophys. Res. Lett., 33(13), L13504. (10.1029/2006GL026319.)

Zemp, M., M. Hoelzle, F. Paul and W. Haeberli. 2007. Glacier fluctuations in the European Alps 1850-2000: an overview and spatio-temporal analysis of available data. In Orlove, B., E. Wiegandt and B.H. Luckman, eds. Darkening peaks: glacier retreat, science, and society. Berkeley, CA, University of California Press.

MS received 18 April 2009 and accepted in revised form 17 January 2010 